\title{
Nutrients Analysis of Diplazium esculentum: Underutilized Wild Wetland Pteridophytes Ensure Food and Nutritional Security
}

\section{Sanjay Mohan Gupta*, Basant Ballabh, Pradeep Kumar Yadav, Ankur Agarwal and Madhu Bala}

Defence Institute of Bio-Energy Research (DIBER), Haldwani, India

*Corresponding Author: Sanjay Mohan Gupta, Defence Institute of Bio-Energy

Research (DIBER), Haldwani, India.
Received: September 24, 2020

Published: October 17, 2020

(C) All rights are reserved by Sanjay Mohan

Gupta., et al.

\section{Abstract}

Food and nutrition (hidden hunger) for rapidly growing global populations (expected to increase 10 billion by 2050 ) are major concern of public health issue in most of the global developing countries. One way to tackle these problems is through the intervention of local traditional less-explored high-value food crops as dietary supplements for ensuring food and nutritional security. The Diplazium esculentum (Retz.) Sw (also called as 'Vegetable fern' or 'Liguna'; fam. Athyriaceae) is an underutilized wild wetland pteridophytes occurring commonly throughout world, from sea level to $2,300 \mathrm{~m}$. The young frond and rhizomes of $D$. esculentum are generally used as green vegetables during the monsoon season, which are reported to possess notable nutritional and medicinal properties. This research article highlights the detailed nutritive phytochemical (primary and secondary metabolites, essential mineral content, dietary fibres, calorific value etc) profiling of young fronds of $D$. esculentum. Our results suggest that $D$. esculentum fronds contains rich amounts of protein (52.3\%), carbohydrate (28.2\%), antioxidants (Vitamin C etc) and exceptionally high contents of important minerals ( $\mathrm{Ca}, \mathrm{Fe}, \mathrm{Na}$ ), dietary fibre (17.44\%) with good calorific energy value (324 Kcal/100 gm). The overall results suggest that, the young fronds of $D$. esculentum contains rich source of phyto-nutrients that may be commercially utilized for the development of healthcare value added products as a sustainable solution to the health and nutritional security.

Keywords: Diplazium esculentum; Edible Ferns; Food and Nutritional Security; Phytonutrient Analysis; Therapeutic Phyto-Constituents; Traditional Vegetables; Wetland Pteridophytes

\section{Abbreviations}

AOAC: Association of Official Analytical Chemists; MUFA: Mono Unsaturated Fatty Acid; NABL: National Accreditation Board for Testing and Calibration Laboratories; PUFA: Poly Unsaturated Fatty Acid; WHO: World Health Organization

Food and nutritional security are presently two foremost problems being faced worldwide. Mineral and protein deficiencies in human populations are one of the greatest health concerns for several developing countries that causing approximately 462 million adults is underweight and around $45 \%$ of deaths among children under 5 years of age are linked to malnutrition (WHO, 2017). To meet this challenge, use of local less-explored, nutritionally rich traditional vegetable crops as dietary supplement for improving mineral and protein deficiencies is advocated [1,2]. In India, from ancient past we have the rich tradition of using local traditional plants with medicinal properties as food as well as in therapeutic diseases [3]. Due to wide range of geographic expansion India is rich in biodiversity thereby providing a rich source of plants with different therapeutic activities waiting to be explored. Especially the wet lands are areas with immense biodiversity, which are yet not properly evaluated for therapeutic plant resources. Several Pteridophytes growing in these wet lands attained very fewer attention of scientific community in spite of having high nutritional and medicinal values [4]. In this effort, the Diplazium esculentum (Retz.) Sw. (English name is 'Vegetable fern' and locally called as 'Li- 
guna'; fam. Athyriaceae) is an important wild edible pteridophyte occurring commonly throughout world, which grows in gregarious colonies in open marshy areas, stream banks and canals from sea level to 2,300m [5]. Young frond and rhizomes of D. esculentum are generally used as green vegetables by tribal population, which is reported to possess notable nutritional and medicinal properties $[6,7]$. Moreover, consuming as vegetable, D. esculentum has been reported to have profound use as traditional medicine in diseases like fever, dermatitis, measles, dysentery, glandular dwellings, indigestion, anthelmintic, analgesic, diabetic, diarrhoea and various skin infections [5,8-10]. Apart from nutritional and medicinal values, liguna is highly adaptive to wet and marshy land and can efficiently withstand various biotic and/or abiotic stresses. These properties thus on the whole make it as excellent model as local traditional high value vegetable crop for addressing health and nutritional security (hidden hunger) issues of growing world population. The detailed nutrient analysis of young fronds of D. esculentum has not been carried out so far. The present research work is an attempt to evaluate detailed nutritive phytochemical (primary and secondary metabolites, essential mineral content, dietary fibres, calorific value etc) analysis of young frond of liguna.

The naturally grown fronds of liguna were collected from its natural habitat as Urgam valley (2200m asl), Distt. Chamoli, Uttarakhand during rainy season in 2019 year (Figure 1a-1c). The mature fronds were thoroughly cleaned with deionized water and chopped into small pieces of size $\left(1-2 \mathrm{~cm}^{2}\right)$ followed by sun drying for 1 week for reducing moisture content (Figure 1d). Completely dried fronds sample was powered in grinder before nutritive phytochemical analyses.

The phyto-nutrients (primary and secondary metabolites) were determined as per the standard biochemical methods described by the Association of Official Analytical Chemists (AOAC) [11-13]. Mineral analysis was carried out after digestion of $2 \mathrm{~g}$ of the grounded sample with $10 \mathrm{~mL}$ of a mixture of nitric acid, sulphuric and perchloric acid (4:1:1, v/v) until a clear solution was obtained. The digest was allowed to cool and then transferred into a $100 \mathrm{~mL}$ volumetric flask and made up to mark with de-ionized water. The mineral elements like sodium, calcium and iron were analysed using atomic absorption spectrophotometer (Perkin Elmer) equipped with air-acetylenes flame. The total dietary fibre and calorific values of samples was estimated according to the study conducted by Pandey., et al [14]. All phytochemical analysis was performed in replicates and data (average) obtained were also verified for genuineness by third part evaluation by reputed NABL accredited lab (EKO PRO Engineers Pvt. Ltd, Ghaziabad).

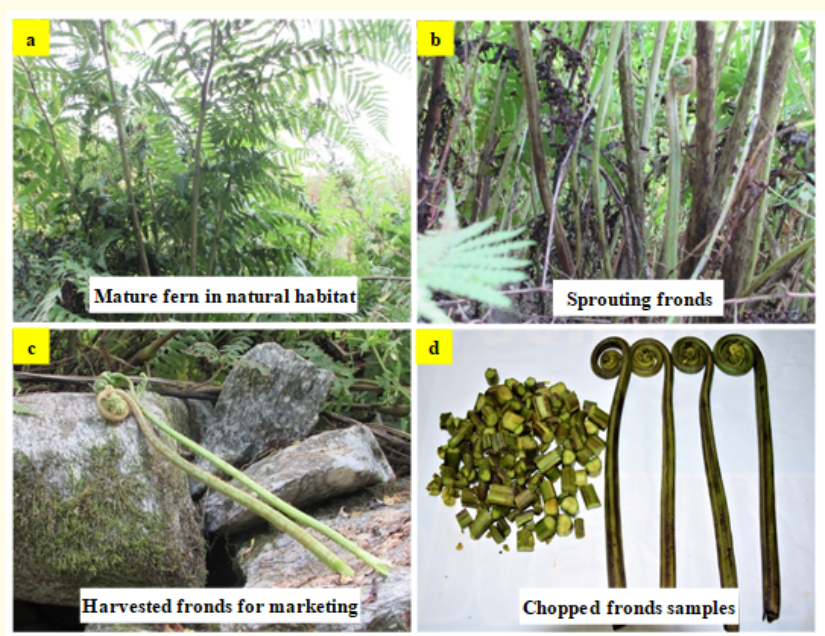

Figure 1: Diplazium esculentum (a) mature fern growing in natural habitat of URGAM valley, Distt. Chamoli, Uttarakhand; (b) mature wild fern under sprouting; (c) harvested fronds for marketing as local traditional vegetable; and (d) harvested chopped fronds samples for phyto-nutrient analysis.

The young fronds of liguna contains significant higher amount of total protein $(52.3 \%)$ and carbohydrate $(28.2 \%)$ as primary metabolites, however, the total sugar and fat content was found low with values of 0.86 and $0.25 \%$, respectively. The fatty acid profiles including MUFA, PUFA, trans fat, saturated fat and cholesterol content was found negligible in fronds of liguna (Table 1). Liguna fronds also contains good amount of secondary metabolites viz. total phenol, tannin and flavonoids content that improves its nutritional value as vegetable as suggested by Tongco., et al [15]. The presence of phenolic and flavonoids contents of liguna fronds may be correlated to their antimicrobial activity [7]. Among antioxidants, Vitamin C contents was found maximum (46 mg/100g), which is in accordance with Zannah., et al [16]. However, Vitamin A and D content was found negligible (Table 1). Among essential minerals, the liguna fronds contain exceptionally higher amount of calcium (Ca), iron ( $\mathrm{Fe}$ ) and sodium ( $\mathrm{Na}$ ) contents with values of 12.25 , 10.71 and $1.18 \mathrm{mg} / 100 \mathrm{~g}$, respectively. The young fronds of liguna also contains good amount of total dietary fibre content (17.44\%), which is good for health as suggested by Veena and Christopher [3]. The total calorific energy of fronds was found (324.13 Kcal/100 gm) that suggest its importance as high value vegetable (Table 1). 


\begin{tabular}{|c|c|c|}
\hline S. No. & Nutrient parameters & $\begin{array}{l}\text { Mature fronds } \\
\text { of D. esculentum }\end{array}$ \\
\hline 1. & Total protein $(\%)$ & 52.31 \\
\hline 2. & Carbohydrate (\%) & 28.15 \\
\hline 3. & Total sugar (\%) & 0.86 \\
\hline 4. & Total fat (\%) & 0.25 \\
\hline 5. & Fatty acid Profile: MUFA (\%) & BLQ* \\
\hline 6. & Fatty acid Profile: PUFA (\%) & $\mathrm{BLQ}^{*}$ \\
\hline 7. & Fatty acid Profile: Saturated fat (\%) & $\mathrm{BLQ}^{*}$ \\
\hline 8. & Fatty acid Profile: Transfat (\%) & BLQ* \\
\hline 9. & Cholesterol (mg/100g) & $\mathrm{BLQ}^{*}$ \\
\hline 10. & Total phenol (mg GAE /100 g FW) & 0.56 \\
\hline 11. & Tannin (mg TAE/g FW) & 0.12 \\
\hline 12. & Flavonoids (mg QE/100 g FW) & 0.16 \\
\hline 13. & Vitamin C (mg/100g) & 46.0 \\
\hline 14. & Vitamin A (mg/100g) & $\mathrm{BLQ}^{*}$ \\
\hline 15. & Vitamin D (mg/100g) & $\mathrm{BLQ}^{*}$ \\
\hline 16. & Sodium (mg/100g) & 1.18 \\
\hline 17. & Calcium (mg/100g) & 12.25 \\
\hline 18. & Iron (mg/100g) & 10.71 \\
\hline 19. & Total Dietary Fibre (\%) & 17.44 \\
\hline 20. & Energy (Kcal/100g) & 324.13 \\
\hline
\end{tabular}

supplement in diet and can also be encouraged to provide seasonal employment to rural and tribal communities. The outcome of nutraceutical analysis of fronds of this underutilized fern is expected to create interest for consumption of local traditional vegetables for nutritional and health security.

\section{Acknowledgments}

Grants received from Defence Research and Development Organization (DRDO), Ministry of Defence, Government of India under project SARHAD (TD/17-18/DIB-78) is duly acknowledged. The technical support received from team members of project SARHAD is also acknowledged.

\section{Conflict of Interest}

The authors declare that they have no conflict of interest.

\section{Bibliography}

1. Lense 0. "Biological screening of selected traditional medicinal plants species utilized by local people of Manokwari, West Papua Province". Nusantara Bioscience 3.3 (2011): 145-150.

2. Bisht IS., et al. "Wild plant food resources in agricultural systems of Uttarakhand hills in India and its potential role in combating malnutrition and enhancing human health". Journal of Food Science and Toxicology 2.1 (2018): 3.

3. Veena G M and Christopher G. "Nutritional value of selected wild edible leaves used by tribal communities of Attappady, Southern Western Ghats". International Journal of Food Science and Nutrition 2.5 (2017): 126-132.

4. Choudhury J., et al. "Antioxidant activity and phytochemical screening of two edible Wetland pteridophytes Diplazium esculentum (retz) sw and Marsilea minuta L. - A comparative study". World Journal of Pharmaceutical Research 3.9 (2017): 195-203.

5. Singh LS., et al. "Ethnobotanical uses of some pteridophytic species in Manipur". The Indian Fern Journal 18 (2002): 14-17.

6. Kaushik A., et al. "FRAP (Ferric reducing ability of plasma) assay and effect of Diplazium esculentum (Retz) Sw. (a green vegetable of North India) on central nervous system". Indian Journal of Natural Products and Resources 3.2 (2012): 228-231.

7. Akter S., et al. "Investigation of In vitro Antioxidant, Antimicrobial and Cytotoxic activity of Diplazium esculentum (RETZ). SW". International Journal of advances in Pharmacy, Biology and Chemistry 3.3 (2014): 723-733. 
8. Amit S., et al. "In-Vitro Anthelmintic Activity of Diplazium esculentum (Retz.) Swiss Rhizome Extract”. Journal of Pharmacognosy and Phytochemistry 1.4 (2012): 84.

9. Chawla S., et al. "Analgesic activity of medically important leaf of Diplazium esculentum". African Journal of Pharmacy and Pharmacology 9.25 (2015): 628-632.

10. Junejo JA., et al. "Exploration of anti-oxidant, anti-diabetic and hepatoprotective activity of Diplazium esculentum- A wild edible plants from North Eastern India". Future Journal of Pharmaceutical Sciences 4 (2018): 93-101.

11. Maynard AJ. "Methods in Food Analysis". Academic Press New York (1970): 176.

12. Harborne JB. "Phytochemical Methods". A guide to modern techniques of plant analysis, $2^{\text {nd }}$ edition. (1984).

13. AOAC. "Official methods of analysis of AOAC International Association of Official Analytical Chemists". Washington, DC, USA (1996).

14. Pandey M., et al. "Evaluation of nutritional composition and antioxidant activity of herbal leaves". The World Journal of Pharmaceutical Sciences Pharmaceutical Sciences 5.8 (2016): 1396-1402.

15. Tongco JVV., et al. "Nutritional and phytochemical screening, and total phenolic and flavonoid content of Diplazium esculentum (Retz.) Sw. from Philippines". Journal of Chemical and Pharmaceutical Research 6.8 (2014): 238-242.

16. Zannah F., et al. "Phytochemical Screening of Diplazium esculentum as Medicinal Plant from Central Kalimantan, Indonesia". AIP Conference Proceedings 1844 (2017): 050001.

\section{Assets from publication with us}

- Prompt Acknowledgement after receiving the article

- Thorough Double blinded peer review

- Rapid Publication

- Issue of Publication Certificate

- High visibility of your Published work

Website: www.actascientific.com/

Submit Article: www.actascientific.com/submission.php

Email us: editor@actascientific.com

Contact us: +919182824667

Citation: Sanjay Mohan Gupta., et al. "Nutrients Analysis of Diplazium esculentum: Underutilized Wild Wetland Pteridophytes Ensure Food and Nutritional Security". Acta Scientific Nutritional Health 4.11 (2020): 46-49. 